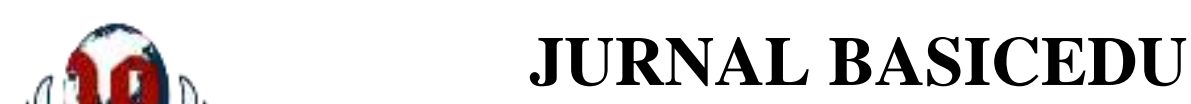

Volume 6 Nomor 1 Tahun 2022 Halaman 552 - 563

Research \& Learning in Elementary Education https://jbasic.org/index.php/basicedu

\title{
Pengembangan Media Pembelajaran Berbasis ICT pada Mata Pelajaran Agama Islam Materi Huruf Hijaiyah dan Harakatnya
}

\author{
Rifa Setiani $Z^{1 凶}$, Erwin Rahayu Saputra ${ }^{2}$ \\ Program Studi Pendidikan Guru Sekolah Dasar, Universitas Pendidikan Indonesia, Indonesia ${ }^{1,2}$ \\ E-mail: rifasetianiz@upi.edu ${ }^{1}$, erwinrsaputra@upi.edu ${ }^{2}$
}

\begin{abstract}
Abstrak
Peserta didik kelas 1 SD masih banyak yang belum paham dan fasih dalam mengucapkan huruf hijaiyah dan harakatnya sesuai dengan kaidah bacaan yang telah ditentukan, sehingga media powerpoint digunakan sebagai sebuah solusi untuk menangani permasalahan tersebut. Berkaitan dengan penggunaan media interaktif power point maka peneliti memiliki tujuan pengembangan yaitu mengetahui keefektifan, keaktifan peserta didik dalam proses pembelajaran serta pemahaman peserta didik pada materi huruf hijaiyah dan harakatya. Metode Pengembangan media pembelajaran powerpoint ini dilakukan berdasarkan pengembangan Research and Development (R\&D) dengan model pengembangan ADDDIE yang terdiri dari 5 tahapan yaitu yaitu analysis, design, development, implementation, and evaluation. Hasil pengimplementasian media powerpoint di SDN 2 Picungremuk berdasarkan respon siswa bahwa keefektifan memiliki nilai persentase $88 \%$ dengan predikat sangat baik dan keaktifan peserta didik dalam proses pembelajaran memiliki nilai persentase $89 \%$ dengan predikat sangat baik.Selanjutnya berdasarkan hasil belajar peserta didik dimana dari 13 peserta didik hanya terdapat 2 peserta didik yang tidak memenuhi kriteria ketuntasan minimal.
\end{abstract}

Kata Kunci: Media Pembelajaran, ICT, Powerpoint, Huruf Hijaiyah, Permainan Edukasi.

\begin{abstract}
There are still many elementary school grade 1 students who do not understand and are fluent in pronouncing the hijaiyah letters and their vowels in accordance with predetermined reading rules, so that powerpoint media is used as a solution to deal with these problems. In connection with the use of interactive power point media, the researcher has a development goal, namely to determine the effectiveness and activeness of students in the learning process and students' understanding of the material of hijaiyah and harakatya letters. The powerpoint learning media development method is carried out based on Research and Development $(R \& D)$ development with the ADDDIE development model which consists of 5 stages, namely analysis, design, development, implementation, and evaluation. The results of implementing powerpoint media at SDN 2 Picungremuk based on student responses that the effectiveness has a percentage value of $88 \%$ with a very good predicate and the activeness of students in the learning process has a percentage value of $89 \%$ with a very good predicate. there are only 2 students who do not meet the minimum completeness criteria.
\end{abstract}

Keywords: Learning Media, ICT, Powerpoint, Hijaiyah Letter, Education Games

Copyright (c) 2022 Rifa Setiani Z, Erwin Rahayu Saputra

Corresponding author :

Email : rifasetianiz@upi.edu

DOI : https://doi.org/10.31004/basicedu.v6i1.1947

ISSN 2580-3735 (Media Cetak)

ISSN 2580-1147 (Media Online)

Jurnal Basicedu Vol 6 No 1 Tahun 2022

p-ISSN 2580-3735 e-ISSN 2580-1147 


\section{PENDAHULUAN}

Pada zaman sekarang yaitu berada pada era globalisasi generasi 4.0 dimana dengan bertambah majunya Ilmu Pengetahuan dan Teknologi (IPTEK) maka kehidupan masyarakat diberbagai bidang didominasi sebagai pengguna teknologi, salah satunya pada bidang pendidikan khususnya dalam proses pembelajaran harus mampu berkembang mengikuti perkembangan dunia IPTEK yaitu informasi dan komunikasi. Guru sebagai pelaksana pendidikan di lapangan dituntut mampu mengembangkan media yang bersifat interaktif dan inspiratif dengan mengikuti perkembangan zaman sehingga bisa menjadikan peserta didik lebih tertarik dan termovitasi untuk mengikuti kegiatan belajar mengajar serta dapat dengan mudah siswa mempelajari suatu materi yang disampaikan oleh guru (Rahmalia N., dkk, 2021).

ICT (Information and Communication Technology) telah menjadi salah satu media pembelajaran yang banyak digunakan untuk meningkatkan efektivitas dan efisiensi dalam proses pembelajaran (Mahdum et al., 2019 ). Media pembelajaran berbasis ICT adalah alat yang digunakan dalam proses pembelajaran dengan memanfaatkan teknologi informasi atau TIK. Media pembelajaran berbasis ICT menurut Putri (2018) diantaranya: teknologi komputer, multimedia, telekomunikasi, dan jaringan komputer. Selain itu menurut Nisa (Arum dan Desstya, 2021). ICT yaitu mencakup berbagai prangkat keras dan lunak yang dapat menyimpan, mengolah serta menyampaikan informasi sehingga dapat terjadi komunikasi. Dengan berkembangnya ICT maka berpengaruh pada perkembangan sistem pendidikan, dimulai dari tingkat dasar hingga tingkat pendidikan tinggi. Berbagai cara dan media telah dikenalkan dan digunakan dalam proses belajar mengajar dengan tujuan agar semakin banyak guru yang memberikan kreatifitas dalam pengajaran dan dapat menghasilkan pembelajaran yang lebih bermakna, tentunya akan meningkatkan mutu pendidikan. Media berbasis ICT ini merupakan media yang bersifat interaktif dikarenakan dengan menggunakan media tersebut siswa tidak hanya menyimak materi, atau hanya memperhatikan penyajian maupun objek melainkan dalam penggunaan media tersebut akan terjadi interaksi yang aktif antara pendidik dan psiswa selama proses pembelajaran (Harsiwi dan Arini, 2020; Luh dan Bagus, 2021).

Dengan menggunakan media pembelajaran berbasis ICT salah satunya dengan bantuan media komputer diharapkan para siswa akan lebih mudah menyerap informasi dan pelajaran, menjadi lebih menarik serta terjadi interaksi lebih baik (interaksi dua arah antara guru dengan peserta didik), sehingga peserta didik dapat tumbuh menjadi pribadi kritis, aktif dan dinamis melalui proses pembelajaran tersebut. Hal tersebut sejalan dengan pendapat (Pulungan, n.d.) bahwa dalam proses belajar mengajar sangat sering ditemui beberapa mata pelajaran yang sangat abstrak atau sulit dimengerti, oleh sebab itu visualisasi pelajaran yang sulit tersebut bisa dengan menggunakan media pembelajaran berbasis ICT, supaya peserta didik mudah untuk memahaminya.

Dalam pembelajaran Pendidikan Agama Islam dan Budi Pekerti peserta didik sering merasa bosan sehingga menjadi malas untuk belajar bahkan mengakibatkan peserta didik tidak bisa memahami materi pembelajaran. Salah satu materinya yaitu huruf hijaiyah dan harakatnya. Dengan hal tersebut dikarenakan proses pembelajaran untuk saat ini yaitu abad 21 maka seorang pendidik harus mampu menggunakan media ICT sebagai alternatifnya. Media pembelajaran yang interaktif untuk digunakan dalam materi huruf hijaiyah dan harakatnya yaitu powerpoint. Powerpoint diasumsikan sebagai media presentasi dan disajikan berdasarkan rangsangan multimedia meliputi, teks, audio, visual, video, animasi dll yang sifatnya dapat dijadikan media pembelajaran interaktif (Muthoharoh, 2019). Jika kita analisis berdasarkan SWOT dari sudut pandang siswa dan guru mengenai media pembelajaran powerpoint. Pertama Strength (Kekuatan): (1) Sudut Pandang Guru: dalam hal pembuatan bahan ajar mudah dan menarik karena tidak hanya berisi tulisan melainkan bisa disertai gambar bahkan video, begitupun dengan proses pembelajarannya menjadi lebih efektif dan efisien. (2) Sudut pandang siswa: proses pembelajaran menjadi menyenangkan dan semakin cepat dalam memahami materi. 
Kedua, Weakness (Kelemahan): (1) Sudut Pandang Guru: template yang tersedia di aplikasi Power Point sedikit sehingga guru harus membuat dan mencari hal tersebut supaya materi bisa disajikan dengan menarik. (2) Sudut Pandang Siswa: materi tidak bisa dipahami kembali secara mandiri dirumah karena isi materi yang dibuat berupa poin-poin saja (penjelasan lebih deatailnya dijelaskan oleh guru). Ketiga, Opportunities (Peluang); (1) Sudut Pandang Guru: a) guru semakin melek teknologi; b) mengembangkan ke kreavitasan guru dalam menyajikan slide presentasi. (2)Sudut Pandang Siswa: melatih daya tangkap peserta didik mengenai apa yang dijelaskan. Keempat Threats (Ancaman): (1) Sudut Pandang Guru: guru yang kurang kreatif dalam memilih dan membuat template presentasi maka slide power point akan terlihat monoton sehingga kegiatan pembelajarannya kurang interaktif. (2) Sudut Pandang Siswa: peserta didik yang kurang mampu dalam hal daya tangkap berpikirnya maka materi yang dijelaskan mengakibatkan tidak bisa dipahami.

Penggunaan media interaktif berbasis ICT tersebut merupakan solusi agar anak-anak nyaman, mudah dimengerti dan fun dalam melakukan pembelajaran materi hijaiyah dan Harakatnya. Berdasarkan PP No. 55 tahun 2007 menjelaskan bahwa pendidikan agama adalah pendidikan yang memberikan pengetahuan dan membentuk sikap, kepribadian dan keterampilan peserta didik dalam mengamalkan ajaran agamanya. Huruf hijaiyah atau huruf arab merupakan dasar dari pelajaran Agama Islam. Peneliti mengkaji beberapa jurnal dan juga dengan melihat di lingkungan kehidupan sehari-hari peneliti bahwasannya di zaman sekarang anak-anak jenjang SD sering memandang sebelah mata mengenai materi tersebut. Sehingga banyak peserta didik kelas 1 SD yang tidak bisa membaca al-qu'an dengan baik dan benar dikarenakan tidak mengetahui dasarnya (huruf hijaiyah dan harakatnya). Peserta didik banyak sekali yang belum bisa membaca huruf hijaiyah sesuai dengan kaidah bahkan sampai ada anak yang belum pernah sama sekali mengetahui huruf hijaiyah. Padahal huruf hijaiyah dan harakatnya merupakan dasar bagi peserta didik yang beragama Islam agar mampu membaca alqur'an dengan lancar sesuai kaidah bacaanya.

Salah satu kajian yang selaras dengan permasalahan tersebut dimana di SD 1 Muhammadiyah Panji bahwasannya Baca Tulis Al-quran (BTQ) dipandang sebelah mata, karena dianggap mudah dan bisa dipelajari di musholla. Padahal berdasarkan realitanya bahwasannya sebagian anak-anak belum bisa membaca huruf hijaiyah dan harakatnya secara baik dan benar sesuai dengan kaidah bacaanya namun setelah melakukan pembelajaran dengan melalui media interaktif powerpoint maka hasil belajar siswa mengalami peningkatan yang cukup baik, sehingga bisa disebutkan bahwa media powerpoint cukup valid untuk digunakan (Victor M, 2019) Tidak hanya dalam pembelajaran Agama saja media powerpoint ini valid untuk digunakan didalam berbagai mata pelajaran salah satunya mata pelajaran IPA. Berdasarkan penelitian (Irfan \& Ristiana, 2019) bahwa dalam pembelajaran IPA media power point sangat layak digunakan baik dari segi aspek tampilan maupun kontennya, berdasarkan penilaian yang dilakukan oleh ahli media maupun materi.

Berkaitan dengan penggunaan media interaktif powerpoint tersebut maka peneliti memiliki tujuan pengembangan yaitu mengetahui keefektifan dan keaktifan peserta didik dalam proses pembelajaran serta pemahaman peserta didik pada materi huruf hijaiyah dan harakatya. Pengembangan media berbasisi ICT yaitu dengan menggunakan powerpoint pada mata pelajaran agama islam untuk tingkat SD dapat diaplikasikan pada penelitian ini. Studi sebelumnya dengan penelitian yang sedang dilakukan memiliki keterkaitan yaitu samasama menggunakan media powerpoint. Perbedaanya terletak pada pengkombinasian powerpoint dengan media lain yang digunakan. Pada penelitian ini media powerpoint interaktif dikombinasikan dengan permainan berbasis digital yang dibuat didalam powerpoint. Sedangkan untuk penelitian sebelumnya yaitu dengan mengkombinasikan pada permainan tradisional yang berupa kartu bergambar (Victor M, 2019). Penelitian ini sangat penting untuk dilakukan agar bisa melihat keefektifan dan keaktifan peserta didik dimana sebelumnya dengan dikombinasikan permaianan tradisional masih bisa dikatakan dengan kategori cukup dalam hal keaktifan dan keefektifan siswa. Maka dengan penelitian kali ini yaitu mengkombinasikan powerpoint dengan permainan berbasis digital untuk melihat keaktifan dan keefektifan siswa dengan kategori yang lebih baik lagi dari cukup serta dapat mengetahui sejauh mana peserta didik tersebut mampu memahami 
sehingga mampu mengamalkan materi tersebut dalam kehidupan sehari-hari sebagai modal peserta didik untuk bisa membaca Al-quran dengan baik.

\section{METODE}

Penelitian pengembangan media pembelajaran Powerpoint dengan dikombinasikan game edukatif ini dilakukan berdasarkan pengembangan Research and Development $(\mathrm{R} \& \mathrm{D})$ dengan model pengembangan ADDDIE yang terdiri dari 5 tahapan yaitu (1) Analysis, (2) Design, (3) Development, (4) Implementation, (5) Evaluatation. Namun dalam penelitian yang dilakukan oleh peneliti ini hanya sampai tahap implementation. Penelitian ini dilakukan selama 2 hari meliputi observasi dan implementasi media di SDN 2 Picungremuk. Subjek penelitian adalah siswa kelas I SD yang berjumlah 13 orang. Teknik pengumpulan data yang digunakan untuk mengumpulkan data pada penelitian ini adalah (1) observasi tidak terstruktur, (2) lembar kuisioner, untuk mengetahui respon siswa setelah melakukan pengimplementasian menggunakan media power point, (3)Hasil belajar siswa.

Intsrumen pengumpulan data meliputi lembar validasi ahli media dan materi serta respon siswa. Penilaian produk yang diperoleh dari hasil uji validasi ahli media dan materi dilakukan menggunakan skala likert. Skor pada setiap kriteria yaitu 5 (sangat setuju), 4 (setuju), 3 (Netral), 2 (tidak setuju), 1 (sangat tidak setuju). Teknik analisis data pada penelitian ini yaitu deskriptif kualitatif dan kuantitatif. Deskriptif kualitatif yaitu untuk mendeskripsikan data yang telah terkumpul dari validasi ahli serta kuisioner respon siswa. Sedangkan deskriptif kuantitatif merupakan pengolahan data yang dilakukan dengan menyusun secara sistematis dalam bentuk angka-angka ataupun persentase untuk mendapatkan kesimpulan umum respon siswa. Angket respon siswa menggunakan skla Gutman. Skor pada kriteria yaitu 1 (Ya) dan 0 (Tidak). Penilaiannya dijabarkan sebagai berikut:

$$
\text { Persentase Skor }=\frac{\sum \text { skor perolean }}{\sum \text { skor maksimum }} \times 100 \%
$$

Setelah memperoleh dari data skor dapat diukur dengan kriteria kelayakan media pembelajaran dapat dilihat pada tabel 1 .

Tabel 1. Rentang persentase dan Kriteria Kelayakan Media

\begin{tabular}{ll}
\hline \multicolumn{1}{c}{ Interval } & \multicolumn{1}{c}{ Kriteria } \\
\hline $85 \%-100 \%$ & Sangat Baik \\
$69 \%-84 \%$ & Baik \\
$53 \%-68 \%$ & Cukup \\
$37 \%-52 \%$ & Kurang Baik \\
$20 \%-36 \%$ & Tidak Baik \\
\hline
\end{tabular}

\section{HASIL DAN PEMBAHASAN}

Penelitian pengembangan menggunakan model pengembangan ADDDIE. Terdapat beberapa tahapan dalam pengembangan media pembelajaran power point huruf hijaiyah dan harakatnya yaitu analysis, design, development, implementation, and evaluation, namun pada penelitian ini peneliti melakukan sampai dengan tahap implementation.

Pertama Analysis, pada tahap ini dengan melalui kegiatan observasi kita dapat menganalisis kebutuhan siswa mengenai masalah yang dihadapi siswa yaitu diperlukan adanya media pembelajaran interaktif. Pada 
tahap ini juga peneliti menentukan media yang akan digunakan dengan melihat karakteristik siswa yaitu media pembelajaran menggunakan powerpoint. Pada tahap ini juga menganalisis kompetensi dasar juga indikatornya. Kompetensi dasar yang digunakan 3.1 mengetahui huruf hijaiyah dan harakatnya secara lengkap dan 4.1 Melafalkan huruf-huruf hijaiyah dan harakatnya secara lengkap. Selanjutnya Indikator yang digunakan meliputi: 3.1.1 Menyebutkan huruf-huruf hijaiyyah dengan benar; 3.1.2 Menunjukkan huruf-huruf hijaiyyah dengan benar; 3.1.3 Menunjukkan huruf-huruf hijaiyah berharakat dengan benar; 4.1.1 Melafalkan huruf-huruf hijaiyah secara lengkap sesuai kaidah sifat dan makhraj hurufnya. 4.1.2 Melafalkan huruf hijaiyah berharakat sesuai kaidah sifat dan makhraj hurufnya. Media interaktif yang akan digunakan dalam membuat media pembelajaran yaitu media pembelajaran menggunakan powerpoint.

Kedua, Design. Tahap ini melakukan perancangan media interaktif yang akan dikembangkan. Tahapan dalam perancangan media media adalah sebagai berikut: 1) menyiapkan bahan pendukung yang akan dipergunakan dalam pengembangan media pembelajaran berbasis powepoint meliputi teks, gambar, video, audio dan slide show yang berkaitan dengan huruf hijaiyah dan harakatnya diantaranya: mengumpulkan bahan berupa gambar huruf hijaiyah; mengumpulkan bahan berupa gambar huruf hijaiyah harakat fathah, Kasrah dan Dhammah; Mencari video mengenai huruf hijaiyah; Mengumpulkan bahan berupa rekaman suara mengenai huruf hijaiyah dan harakatnya; 2) Membuat storyboard. 3) Penyusunan instrumen penilaian produk berupa kuisioner. Kuisioner ditunjukan untuk melihat respon siswa setelah uji coba lapangan sebagai sasaran implementasi produk.

Ketiga Development. Menurut Irwan (Dewi \& Handayani, 2021) bahwa tahap development tersebut dimana komponen yang telah dibuat dari tahap analisis dan desain disatukan menjadi satu dan diubah kedalam bentuk media yang nyata. Jadi pada tahap ini produk yang sudah didesain dan dirancang dengan storyboard maka dikembangkan menjadi produk nyata dengan menggunakan aplikasi powerpoint. Pada tahap ini yang dilakukan diantaranya (1) Memilih warna dan membuat background untuk slide presentasi. (2) Membuat tombol menu home (kompetensi dasar, profil, materi dan permainan). (3) Membuat slide profil, dan kompetensi dasar, (4) Memasukan gambar dan video berupa lagu mengenai huruf hijaiyah kedalam slide presentasi. (5) Memasukkan audio format wav dengan bentuk hyperlink pada setiap gambar huruf hijaiyah dan harakatnya sehingga ketika diklik akan mengeluarkan suara pelafalan dari gambar tersebut. (5) Membuat game edukatif untuk evaluasi, tahapan-tahapannya: memasukan gambar, menuliskan teks pertanyaan, memasukan audio pertanyaan (rekaman biasa dan hyperlink), memasukan audio format wav mengenai bunyi salah dan benar jika menjawab pertanyaan. Produk pengembangan media pembelajaran powerpoint interaktif dapat dilihat pada tabel 2.

Tabel 2. Produk Media Pembelajaran Berbasis Powerpoint

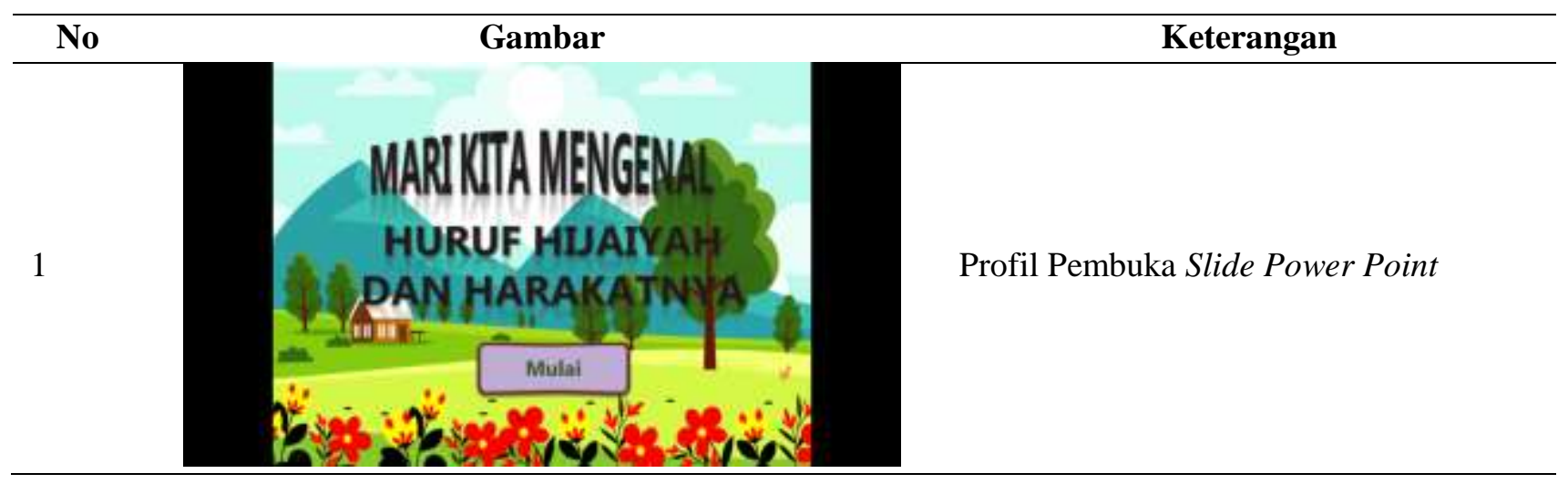



Hijaiyah dan Harakatnya - Rifa Setiani Z, Erwin Rahayu Saputra DOI: https://doi.org/10.31004/basicedu.v6il.1947

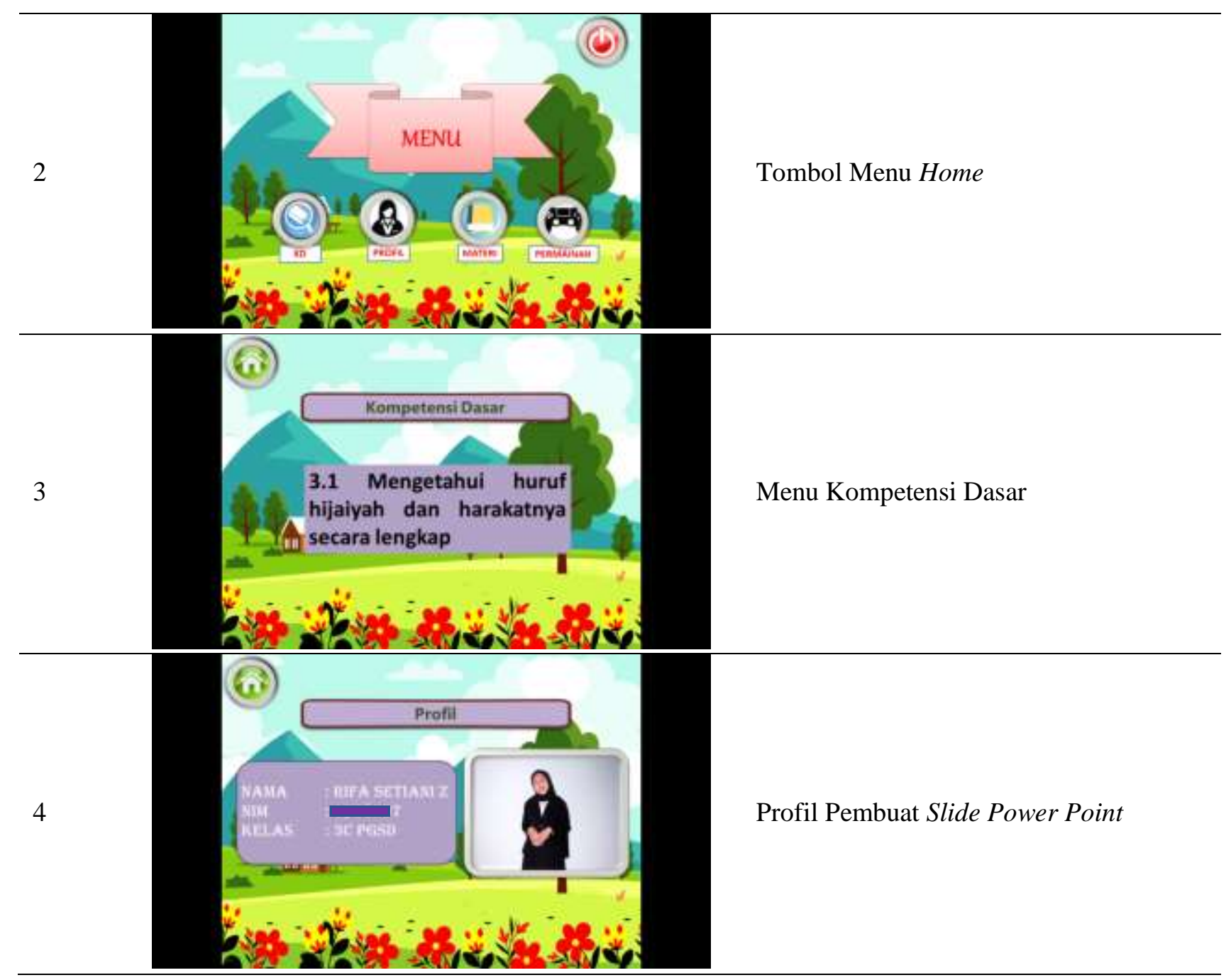



Hijaiyah dan Harakatnya - Rifa Setiani Z, Erwin Rahayu Saputra DOI: https://doi.org/10.31004/basicedu.v6i1.1947
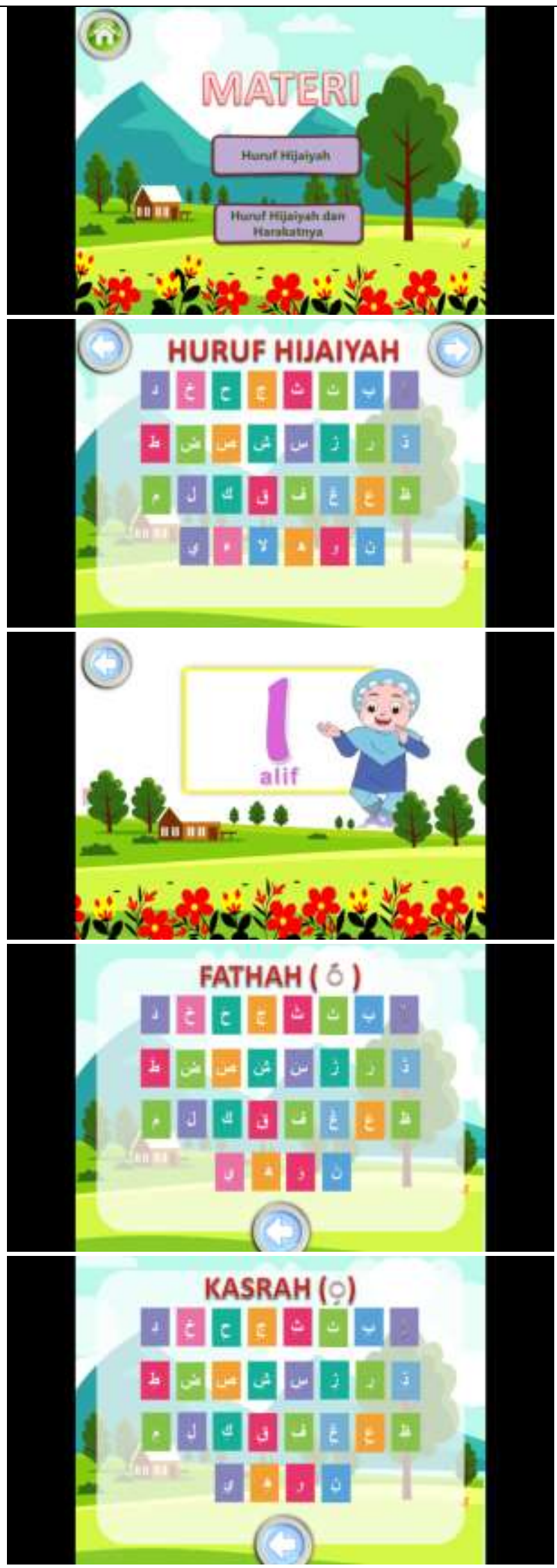

Menu Materi

Materi Huruf Hijaiyah

Nyayian huruf hijaiyah

Materi Huruf Hijaiyah Harakat Fathah

Materi Huruf Hijaiyah Harakat Kasrah 


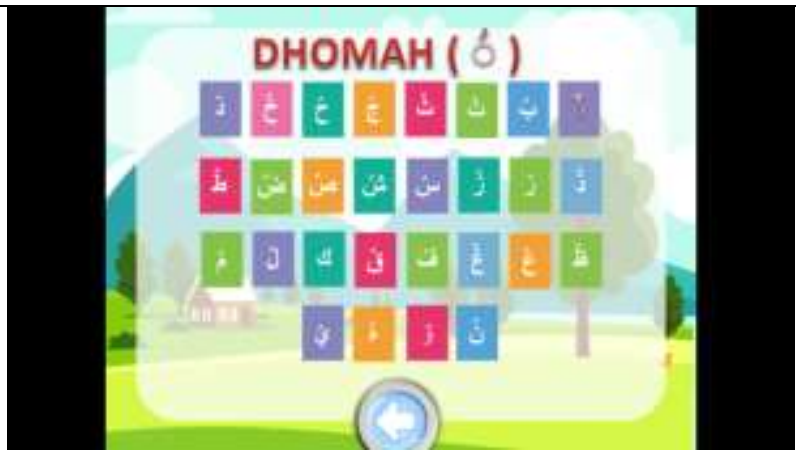

Materi Huruf Hijaiyah Harakat Dhomah
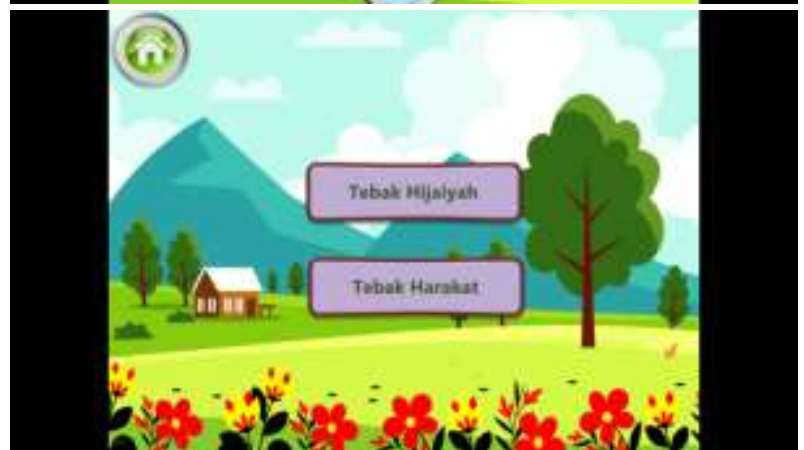

Menu pada Permainan

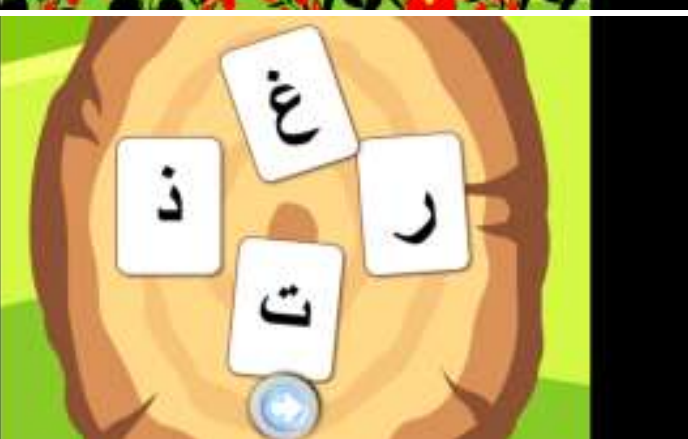

Permainan Tebak Hijaiyah

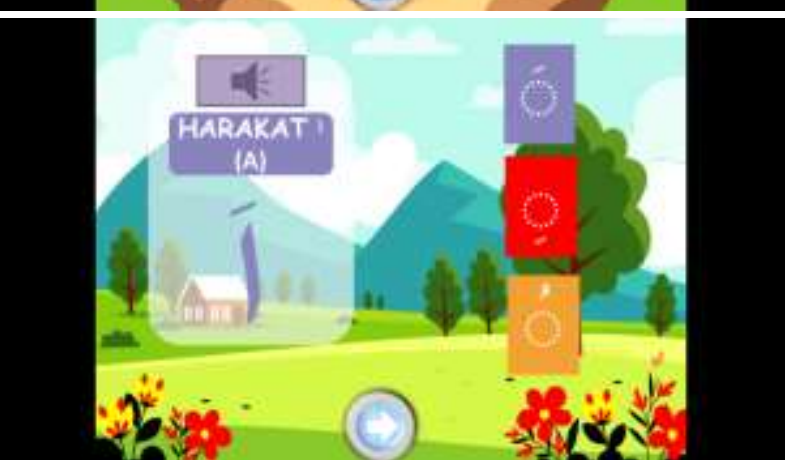

Permainan Tebak Harakat

Pada tahap development ini juga melakukan kegiatan validasi oleh tim ahli materi dan media untuk mengetahui produk yang dikembangkan layak atau tidak. Validasi dilakukan oleh Dosen Pengampu Mata Kuliah Literasi ICT dan Media Pembelajaran di SD yang bernama Dr. Erwin Rahayu Saputra, M.Pd dan hanya dilakukan satu kali saat pemaparan desain produk. Pada tahap validasi dikatakan layak untuk diimplementasikan. Karena beliau mengatakan bahwa media tersebut dengan isi konten, pemilihan tulisan serta kombinasi warna yang digunakan pada background sangat sesuai dengan karakteristik siswa kelas 1 SD. Dengan demikian maka produk tersebut tidak ada yang harus direvisi.

Keempat implementation. Tahap ini produk yang sudah dikembangkan maka di implementasikan. Kegiatan implementasi yaitu di SDN 2 Picungremuk dengan jumlah siswa 13 orang. Tahap ini dilakukan 
untuk melihat respon siswa dan hasil belajar siswa dimana media yang dibuat berhasil menjadi solusi atas permasaalhan yang sebelumnya terjadi. Hasil respon siswa dapat dilihat pada tabel 3.

Tabel 3. Hasil Kuisioner Respon Siswa

\begin{tabular}{|c|c|c|c|c|c|}
\hline Indikator & Kategori & $\begin{array}{c}1 \\
(\mathbf{Y a})\end{array}$ & $\begin{array}{c}\text { 0 } \\
\text { (Tidak) }\end{array}$ & Persentase & Predikat \\
\hline \multirow[t]{3}{*}{ Penyajian } & $\begin{array}{l}\text { Teks pada power point terlihat } \\
\text { sangat jelas }\end{array}$ & 13 & 0 & \multirow[t]{3}{*}{$100 \%$} & \multirow[t]{3}{*}{ Sangat Baik } \\
\hline & $\begin{array}{l}\text { Gambar pada media power } \\
\text { point terlihat jelas }\end{array}$ & 13 & 0 & & \\
\hline & $\begin{array}{l}\text { Video pada media powerpoint } \\
\text { suaranya terdengar jelas }\end{array}$ & 13 & 0 & & \\
\hline \multirow[t]{2}{*}{ Keefektifan } & $\begin{array}{l}\text { Pembelajaran } \\
\text { menggunakan } \\
\text { powerpoint materinya mudah } \\
\text { dipahami dikarenakan dikemas } \\
\text { dengan tampilan yang menarik }\end{array}$ & 11 & 2 & \multirow[t]{2}{*}{$88 \%$} & \multirow[t]{2}{*}{ Sangat Baik } \\
\hline & $\begin{array}{l}\text { Pembelajaran dengan } \\
\text { menggunakan media power } \\
\text { point membuat pembelajaran } \\
\text { lebih terarah dan terpusat. }\end{array}$ & 12 & 1 & & \\
\hline \multirow[t]{5}{*}{ Keaktifan } & $\begin{array}{l}\text { Game dalam powerpoint } \\
\text { sangat } \\
\text { sehingga saya selalu ingin } \\
\text { mencobanya. }\end{array}$ & 13 & 0 & \multirow[t]{5}{*}{$89 \%$} & \multirow[t]{5}{*}{ Sangat Baik } \\
\hline & $\begin{array}{lr}\text { Pembelajaran } & \text { dengan } \\
\text { menggunakan } & \text { media }\end{array}$ & 11 & 2 & & \\
\hline & $\begin{array}{l}\text { powerpoint membuat saya } \\
\text { penasaran ketika ada materi } \\
\text { yang tidak dimengerti } \\
\text { sehingga selalu bertanya. }\end{array}$ & & & & \\
\hline & $\begin{array}{lr}\text { Pembelajaran } & \text { dengan } \\
\text { menggunakan } & \text { media }\end{array}$ & 11 & 2 & & \\
\hline & $\begin{array}{l}\text { powerpoint membuat saya } \\
\text { bersemangat dan dapat } \\
\text { memotivasi untuk terus belajar }\end{array}$ & & & & \\
\hline Rata-Rata & & & & $92 \%$ & Sangat Baik \\
\hline
\end{tabular}

Berdasarkan tabel 3, bahwa pengimplementasian media power point interaktif dengan dikombinasikan dengan game edukatif ini memiliki nilai rata-rata $92 \%$ predikat sangat baik yang menunjukkan hasil positif pada siswa mengenai materi huruf hijaiyah dan harakatnya dikarenakan dengan media tersebut dapat memberikan pengalaman yang bermakna bagi siswa karena dapat meningkatkan minat, focus, dan aktifnya siswa pada saat kegiatan belajar mengajar berlangsung (Chrismawati dan Septiana, 2021; Pramitha P, 2021). Sedangkan menurut Rahmalia N, dkk (2021) mengatakan bahwa pengalaman yang bermakna diasumsikan sebagai suatu proses yang digunakan untuk mengarahkan siswa pada situasi yang dapat membantu siswa sehingga bisa mencapai tujuan pembelajaran. Dengan media interaktif ini maka siswa bisa beajar untuk mandiri.

Terdapat dua indicator yang tidak memiliki nilai persentase yang sempurna $100 \%$. Pertama indikator keefektifan, dimana nilai persentasenya $88 \%$ predikat sangat baik, yang terdapat 2 kategori meliputi kategori kepahaman terhadap materi yang dikemas dengan tampilan yang menarik dan kategori pembelajaran lebih 
terarah dan terpusat. Menurut Widhayanti dan Abduh (2021) media powerpoint itu bersifat efektif dikarenakan menjadikan guru mudah untuk mentransfer ilmu dengan cara presentasi mengenai materi huruf hijaiyah dan harakatnya sehingga peserta didik juga akan menjadi lebih terfokus pada materi yang dijelaskan, serta dapat dengan mudah guru menguasai kelas.

Kategori kepahaman terhadap materi yang dikemas dengan tampilan yang menarik, terdapat dua orang siswa berinisial ZA, dan MRB yang masih belum paham. Selanjutnya kategori lebih terarah dan terpusat terdapat 1 orang siswa berinisial MDF yang memiliki permasalahan pada kategori tersebut. Berdasarkan penuturan peserta didik yang bersangkutan mengatakan bahwa dengan menggunakan powerpoint interaktif yang dikombinasikan dengan game edukatif ini tidak terlalu terarah dengan baik dikarenakan system belajarnya dengan cara berkerumun serta pada saat kegiatan permainan edukatif harus cepat-cepat antri tidak dipanggil berdasarkan absensi.

Kedua, terkait dengan keaktifan dengan nilai persentase $89 \%$ predikat sangat baik meliputi kategori game yang menyenangkan, semangatnya belajar (memotivasi siswa) dan keaktifan belajar. Penelitian dengan kategori bahwa powerpoint dapat memberikam motivasi pada siswa hal tersebut pernah dilakukan oleh (Yuliza, 2018; Trihariyanto dkk, 2020) bahwa di SDN Negeri 86 Kota Bengkulu, SDIT Muhammadiyah Sinar Fajar Cawas, dan SD Muhammadiyah Program Khususs Bayat dimana powerpoint memiliki pengaruh besar terhadap motivasi belajar siswa yang dapat menjadikan siswa bersemangat mengikuti proses pembelajaran,dan menambah daya fokus.

Kategori game yang menyenangkan tidak terjadi masalah pada semua siswa. Tingkat perkembangan siswa sekolah dasar merupakan anak yang memiliki karakteristik suka bermaian sehingga jika suatu media tersebut terdapat kegiatan permainannya maka anak akan merasa senang. Permainan tersebut tidak hanya berupa penggunaan media konkret namun bisa dengan menggunakan media berbasis digital (Ariani E, 2019). Media pembelajaran powerpoint ini dikolaborasikan dengan game edukasi. Game edukasi merupakan sebuah permaian yang dikemas dengan konteks pendidikan yang dapat medidik siswa serta dapat membentuk proses kepribadian anak mencapai perkembangan, fisik, intelektual, social, moral, emosional dan pengetahuannya yang didalamnya terdapat peraturan yang harus dipatuhi (Gunawan Saputra 2018; Prasetyo dan Astuti; 2021). Kategori semangatnya belajar dan keaktifan belajar terdapat 2 orang siswa yang memilih permasalahan dalam indicator tersebut, dimana siswa tersebut yaitu siswa yang sama pada permasalahan indicator kepahaman materi berinisial ZA dan MRB dikarenakan dari awal terasa susah dipahaminya maka menurut dia tidak dapat membuat dirinya semangat belajar dan tidak aktif ketika pembelajaran.

Selanjutnya dalam kegiatan implementasi juga terdapat evaluasi pembelajaran untuk melihat hasil belajar peserta didik. Hasil belajar peserta didik dari keseluruhan melebihi kriteria ketuntasan minimal yaitu 77. Dari hasil penelitian tersebut menunjukkan bahwa penggunaan powerpoint sebagai media sudah memenuhi prinsip penggunaan yaitu mengarahkan untuk mempermudah siswa belajar dalam upaya meningkatkan hasil belajar terutama dalam mata pelajaran agama (Irwanto, 2020). Dengan kriteria ketuntasan minimal 77 terdapat 2 peserta didik yang tidak memenuhi kriteria ketuntasan minimal tersebut. Meskipun demikian dari keseluruhan hasil belajar dapat disimpulkan bahwa dengan media pembelajaran powerpoint dapat mengatasi permaslahan yang terjadi dimana hasil siswa bisa dikatakan memuaskan serta keefetifan dan keaktifan peserta didik jauh lebih baik lagi dari pada kegiatan belajar mengajar yang dilakukan tanpa menggunakan media powerpoint dengan dikombinasikan game edukatif.

\section{KESIMPULAN}

Penggunaan media powerpoint interaktif yang dikombinasikan dengan game edukatif pada mata pelajaran agama islam materi huruf hijaiyah dan harakatnya dengan melihat respon siswa nilai rata-ratanya yaitu $92 \%$ predikat sangat baik. Angket respon peserta didik tersebut memiliki beberapa indicator penilaian 
diantaranya meliputi, indicator penyajian dengan nilai persentase $100 \%$ predikat sangat baik, keefektifan memiliki nilai persentase $88 \%$ dengan predikat sangat baik dan keaktifan memiliki nilai persentase $89 \%$ dengan predikat sangat baik. Selain itu juga dengan melihat hasil belajar siswa, dimana dari 13 peserta didik hanya terdapat 2 peserta didik yang tidak memenuhi kriteria ketuntasan minimal. Dengan demikian dari hasil angket respon dan hasil belajar peserta didik maka media pembelajaran powerpoint ini sangat membantu guru dan siswa dalam kegiatan belajar mengajar sehingga lebih efektif dan aktif dalam proses pembelajarannya.

\section{UCAPAN TERIMA KASIH}

Saya ucapkan terimakasih kepada dosen pengampu mata kuliah literasi ICT dan media pembelajaran di SD yang bernama Dr. Erwin Rahayu Saputra, M.Pd yang telah membimbing dan sekaligus melakukan validasi pada produk yang saya buat. Selanjutnya saya ucapkan terimakasih juga kepada bapak kepada sekolah SDN 2 Picungremuk yang bernama Juanda, S.Pd. Ibu wali kelas 1 yaitu Euis Mustika, S.Pd serta para peserta didik kelas 1 SD yang telah memberikan saya kesempatan untuk melakukan kegiatan observasi dan implementasi media pembelajaran powerpoint interaktif.

\section{DAFTAR PUSTAKA}

Ariani Erwin, V. 2019. Multimedia Interaktif Bermuatan Permainan Edukatif Di Kelas V Sekolah Dasar. Jurnal Basicedu, 3(3), 901-908 Retrieved From Https://Jbasic.Org/Index.Php/Basicedu

Arum, M. S., Dan Desstya, A. 2021. Analisis Kebutuhanpengembangan Media 21stvidokiberbasis Modalitas Belajar Pada Materi Fungsi Pencernaan Pada Manusia. Jurnal Basicedu, 5(6), 5428-5435. Https://Doi.Org/10.31004/Basicedu.V5i6.1559

Chrismawati, M., Dan Septiana, I. 2021. Peningkatan Hasil Belajar Melalui Model Flipped Classroom Berbantuan Media Power Point Dan Audio Visual Di Sekolah Dasar. Edukatif: Jurnal Ilmu Pendidikan, 3(5), 1928-1934. Https://Doi.Org/10.31004/Edukatif.V3i5.695

Dewi, F. F., Dan Handayani, S. L. 2021. Pengembangan Media Pembelajaran Video Animasi En-Alter Sources Berbasis Aplikasi Powtoon Materi Sumber Energi Alternatif Sekolah Dasar. Jurnal Basicedu, 5(4), 2530-2540. Https://Doi.Org/10.31004/Basicedu.V5i4.1229

Gunawan Saputra, H. (2018). Pengaruh Penggunaan Media Ms Powerpoint Berbasis Game Terhadap Hasil Belajar Siswa. In Jurnal Teknologi Pendidikan. 3 (1), 11-19

Harsiwi, U. B., Dan Arini, L. D. D. 2020. Pengaruh Pembelajaran Menggunakan Media Pembelajaran Interaktif Terhadap Hasil Belajar Siswa Di Sekolah Dasar. Jurnal Basicedu, 4(4), 1104-1113. Https://Doi.Org/10.31004/Basicedu.V4i4.505

Irfan, P., \& Ristiana, E. 2019. Media Pembelajaran Ipa Berbasis Powerpoint Di Sekolah Dasar. Indonesian Journal Of Primary Education, 3(2), 16-27.

Irwanto. (2020). Implementasi Multimedia I-Spring Dengan Powerpoint Untuk Meningkatkan Hasil Belajar Pada Pembelajaran Salat Untuk Mata Pelajaran Pendidikan Agama Islam (Implementation Of I-Spring Multimedia With Powerpoint To Improve Learning Outcomes In Praying Learning For Islamic Religious Education Learning). Pedagogi: Jurnal Penelitian Pendidikan, 7(1), 65-78. Retrieved From Https://Journal.Uniku.Ac.Id/Index.Php/Pedagogi

Luh, N. S. D. P., Dan Bagus, I. M. S. (2021). Pengembangan Media Pembelajaran Powerpoint Interaktif Pada Mata Pelajaran Ipa Siswa Kelas Vi Sd. Jurnal Penelitian Dan Pengembangan Pendidikan, 5(1), 76-83. Retrieved From Https://Ejournal.Undiksha.Ac.Id/Index.Php/Jj1/Index 
Mahdum, M., Hadriana, H., Dan Safriyanti, M. 2019. Exploring Teacher Perceptions And Motivations To Ict Use In Learning Activities In Indonesia. Journal Of Information Technology Education: Research, 18, 293-317. Https://Doi.Org/10.28945/4366

Muthoharoh, M. 2019. Media Powerpoint Dalam Pembelajaran. Tasyr'i: Jurnal Tarbiyah Syari'ah Islam, 26 (1), 21-32.

Peraturan Pemerintahan No. 5 Tahun 2007 Tentang Pendidikan Agama Dan Pendidikan Keagamaan.

Pramitha Putri, H. 2021. Pengaruh Media Pembelajaran Power Point Interaktif Terhadap Hasil Belajar Ips Siswa Sekolah Dasar. Edukatif: Jurnal Ilmu Pendidikan, 3(6), 3538-3543. Https://Doi.Org/10.31004/Edukatif.V3i6.986

Prasetyo, A. F. D., Dan Astuti, S. 2021. Pengembangan Media Pembelajaran "Ormas" (Organ Tubuh Manusia) Berbasis Aplikasi Microsoft Power Point Di Sekolah Dasar. Jurnal Basicedu, 5(3), 1198-1209. Https://Doi.Org/10.31004/Basicedu.V5i3.865

Pulungan, S. N.D.. Pemanfaatan Ict Dalam Pembelajaran Pai. Jurnal Sistem Informasi, 1(1), 19-24.

Putri, R. E. 2018. Penerapan Metode Pembelajaran Matematika Berbasis Ict Pada Sdn 14 Kecamatan Lubuk Begalung Padang. Intecoms: Journal Of Information Technology And Computer Science, 1(1), 91-99. Https://Doi.Org/10.31539/Intecoms.V1i1.162

Rahmalia Natsir, S., Dkk. 2021. Analisis Kesulitan Guru Sekolah Dasar Negeri Pesisir Pantai Kota Baubau Dalam Pembelajaran Matematika Pada Masa Pandemik Covid-19. Jurnal Basicedu, 5(6), 5014-5023. Https://Doi.Org/10.31004/Basicedu.V5i6.1472

Victor M. 2019. Penggunaan Media Permainan Dalam Power Point Untuk Meningkatkan Hasil Belajar Membaca Huruf Hijaiyah Dan Harakat Kelas 1 Sd Muhammadiyah Panji. Journal Education Research And Development., 3(2), 141-148.

Trihariyanto S., Dkk. 2020. Strategi Pembelajaran Inovatif Pendidikan Agama Islam Dengan Media Powerpoint Dalam Meningkatkan Mutu Pendidikan Di Sdit Muhammadiyah Sinar Fajar Cawas Dan Sd Muhammadiyah Pk Bayat. Jurnal Studi Islam, 21(1), 109-120. Retrieved From Https://Www.Unm.Ac.Id/Files/

Widhayanti, A., Dan Abduh, M. 2021. Peningkatan Motivasi Belajar Melalui Media Audiovisual Berbantuan Power Point Pada Peserta Didik Di Sekolah Dasar. Edukatif: Jurnal Ilmu Pendidikan, 3(4), 1587-1593. Https://Doi.Org/10.31004/Edukatif.V3i4.627

Yuliza, S. (2018). Penggunaan Metode Audio Visual Dan Media Pembelajaran Microsoft Power Point Terhadap Motivasi Belajar Siswa Pada Mata Pelajaran Pendidikan Agama Islam Di Sd Negeri 86 Kota Bengkulu. Al-Basthu, 3 (1), 61-79 